\title{
Exploring the symbolism of traditional Szekely gates in heritage tourism
}

\author{
Mihaela Preda*, Ana Irina Lequeux-Dincă, Iuliana Vijulie, \\ Alina Mareci, Ana-Maria Taloş, Anca Tudoricu
}

\author{
University of Bucharest, Romania
}

Gates represent an important component of the Romanian domestic life since historical times. They function as a barrier between the sacred family space from inside the household and the space and potential dangers from outside it. Traditional wooden gates have been inscribed with specific elements, thus functioning simultaneously as a household utility and conserving a common identity through their symbolism. Szekely gates represent a lesserknown and studied element of ethnocultural heritage, although the area where they are located has been in the last few years and will probably continue to be a very dynamic and sought after tourism destination. The wooden Székely gates, found in areas inhabited by this ethnic minority, represent a true accumulation of both Romanian and Székely rituals and symbols. The aim of the study is to highlight the importance of the gates for the traditional ethnographic heritage of this ethnic minority with real implications for the development of local cultural and heritage tourism. The objectives of the study consist in identifying the main areas of distribution for Székely gates in Transylvania, the significance of their main symbols and the level of their current national and international promotion. The research methodology included direct observations, GIS techniques, and field investigations. The results of this exploratory study show the location of the traditional Székely gates and their diversity, and the coexistence of a Romanian symbolism with one that is exclusively local through specific motifs and colours. This diversity and coexistence of symbols gives the possibility of inserting Székely gates as added cultural values into an already visible and viable tourism area.

Key Words: Székely gates, cultural heritage, tourism, symbolism, Romania.

Article Info: Received: November 28, 2017; Revised: April 2, 2018; Accepted: May 5, 2018; Online: May 25, 2018.

\footnotetext{
* Corresponding author

Address: Faculty of Geography, University of Bucharest, Blvd. Nicolae Bălcescu, no. 1, 010041, Bucharest, Romania.

Phone: +4.0727.784.038 | Email: mihaela.preda@geo.unibuc.ro
}

(C)2018 Human Geographies; The authors

(c) (i) This work is licensed under a

Creative Commons Attribution 4.0 International License. DOI:10.5719/hgeo.2018.121.5 


\section{Introduction}

Identity, in general, represents an individual self-identification action while ethnical identity is constructed through rituals, language, religion, values, morals, and etiquettes (Webster, 1994). Moreover, ethnical identity stands out as a complex psychological process, which entails knowledge, perceptions, feelings, beliefs, and convictions (Cohen, 1975; Cohen, 1993). A series of studies have shown that populations living in multicultural societies tend more often to establish a set of ethnical identity features that will make them easier to stand out inside their community (Markus and Kunda, 1986).

With the ever-growing spectrum of international commerce, globalization, migration, and tourism, consumer request for cultural identity elements, individuality, and uniqueness increases (Webster, 1994) and ethnic identity is often cited as one of the main tools for developing tourism and cultural heritage (Picard and Wood, 1997, Azmi and Ismail, 2016).The diversity of traditional cultural heritage attracts various specialists more and more with research approaches varying from preserving its potential to capitalization through tourism. Certain authors called heritage the 'buzz' word of the 90s, and it represents one of the most significant and fastest growing components of tourism to which a whole range of studies and approaches was dedicated (Poria et al., 2003).

"The term 'cultural tourism' which is used interchangeably with 'heritage tourism' or 'ethnic tourism' usually offers tourists the attraction of cultural traditions, places and values such as religious practice, folklore traditions and social custom of certain communities or ethnic" (Azmi and Ismail, 2016).

The representation of minority culture is obviously considered central to the development of ethnic tourism (Yang, 2011) and through ethnic tourism, holiday makers may benefit during their cultural experience both from tourist gaze on unique cultural elements and from the social interaction with local communities (Azmi and Ismail, 2016). The rationale behind encouraging ethnic tourism development is the fact that tourism acts in the end as a tool for heritage preservation and conservation (Lussetyowati, 2015) as well as for the economic and cultural development of a site or area (Yang, 2011).

Certain authors underline, however, an evolutionary trend in the concept of heritage tourism, which detached itself from a descriptive approach and embraced more and more an experiential approach within what is called the process of 'heritagisation'. This process refers mainly to the use and interpretation of the past for the benefit of the general public, as particularised in the case of Romanian museums by Dumbrăveanu et al. (2016). It can also work for the benefit of the community and uses but does not rely entirely on preservation and conservation, but instead focuses on objects and presents the core of cultural tourism (Poria and Ashworth, 2009).

Although the specialized literature on heritage tourism dedicated to ethnic minorities is extensive, and tourists' interest for indigenous communities cultures is well documented, studies on this subject follow largely two types of approaches: quantitative approaches based on questionnaires tourist fill in at the end of their visits, or analysing the interactions of western tourists with exotic indigenous communities (Yang et al., 2013). Even studies that focus on heritage 
tourism practised by locals in rural areas with high concentration of ethnic minorities are not typical for countries from Central and Eastern Europe and implicitly Romania, although the country benefits from numerous examples of cultural resources consumed and promoted by national and international tourists. One cause can be the degree in which the cultural and ethnical material and immaterial resources are known, acknowledged, and integrated by authorities and profile institutions (e.g. tour operators or tourism agencies) in their local or regional development strategies and/or promotional products. Such a situation was illustrated by Silva and Leal (2015) in the case of Historic Villages of Portugal.

Elements specific to ethnic minorities that can constitute both material and immaterial heritage goods can contribute to the development of tourism activities, which in turn, if valued sustainably, can function as economic support for local communities (André, 2011; Ballesteros et al., 2006; OECD, 2009). Romania's natural and human heritage represents a resource pool for a series of activities through which ecotourism, rural tourism or heritage tourism should be developed with the precondition of keeping its content as goods (material or immaterial) that belong to the community (Matei, 2011). Heritage tourism may be simultaneously the reason and the factor that contribute to the preservation and the conservation of tangible and intangible elements of ethnic culture, especially when there are strong interactions between spatial structures and ethnicity (Madut, 2017) as it is the case in different regions of Romania (e.g. Banat, Bucovina, Szekely lands etc.).

In certain areas of the country, for example, there is a well-developed wood processing culture with the most famous one being Maramureş, followed by Bucovina and maybe the less known areas inhabited by Székely population (Pop et al., 2013). Traditional houses and households, wooden churches, and traditional wooden gates are part of sustainable cultural itineraries and are intensely promoted as highly important tourism objectives pertaining to the country's cultural heritage (Dessein et al., 2015).

Szekely gates are representative cultural elements located in areas inhabited by this ethnic minority and their construction processes, use of wood, symbolism, and colour palette function as conduits for information about the community (Comşa, 2013). As such, they can be seen and used as a valuable element in the practice of heritage tourism in the area they are located.

\section{Methodology}

The study aims to establish the representation area for the Szekely ethnographic heritage embodied by Szekely wooden gates, to emphasise their cultural implications for preserving an ethnic identity, and to demonstrate their potential for the development of cultural and heritage tourism. The objectives of the study included identifying: the main areas of distribution for Székely gates in Transylvania, the significance of their main symbols (motifs, colours, sculptures, paintings) and the level of their current national and international tourism promotion.Szekely gates represent a lesser-known and studied element of ethno-cultural heritage, although the area where they are located has been in 
the last few years and will probably continue to be a very dynamic and sought after tourism destination.

The research methodology was based on field investigations, as there are no statistical databases or relevant studies regarding cultural and tourism itineraries for this subject because Szekely gates have mostly local importance. The field investigations had two stages.

During the first stage, which took place in 2017 between January 5 and 20, observation charts were filled in. This first stage aimed to cover all the localities in which Szekely gates could be present and to measure the degree of representation of these gates in the study area in order to establish to what extent these ethnocultural heritage elements still exist. Other objectives for this stage were studying the typology of the gates (painted wooden gates, sculpted wooden gates, gates with dovecote), as well as their symbolism both regarding sculpting motifs and dominant colours. The metadata provided by the observation charts were used to construct a map depicting the location and type of Szekely gates. The authors used ArcGIS 9.3 software for this stage. The map shows administrative-territorial units classified as communes where the presence of two types of gates was marked: sculpted wooden gates and painted wooden ones.

The second stage of the field investigation took place in 2017 between 20 and 27 of April and consisted in applying semi-structured interviews in two wellknown tourism localities (Praid and Corund), where 20 such guides were conducted. The objectives if the semi-structured interview were identifying elements such as gates' lifespan, the person (artisan) that built them, the meaning of the gate' size, choice of decorative symbols (sculpting), and reasons for still keeping the tradition of having Szekely gates. The sampling method required that the interviewed population was local and covered all age categories but most importantly that they were among those still keeping as part of their household traditional Szekely gates. The results of these guides were coded using QSR Nvivo 11. This program also provided descriptive analysis that better presented the variables encountered in the field. This type of analysis enables the description, emphasis, and resuming of data through a process of decontextualising the causes, the reasons, and arguments of the respondents (Blismas and Dainty, 2003; Jones, 2007).

The current level of promotion of Szekely gates was analysed by canvasing online sources in order to assess the level of promotion of the tourism attractions located in the study area and pinpoint mentions of Szekely gates. Also, the study aims to measure the current tourism capitalization of the area and to make a prognosis of its future situation. Texts from sites that promoted tourism objectives were analysed in terms of word similarity using the QSR Nvivo 11 software, by identifying two types of actors: travel agency and other sources (like travel blogs, media tourism articles, or interviews with local promoters, general presentation web pages of the study area).

In order to assess the potential tourism valorisation a well-known indicator of tourism activity has been considered, respectively the accommodation capacity of the area identified as the study area. The accommodation capacity represents the number of beds and has five categories: <10, 11-50, 51-100, 101-200, 201$500,>500$. The accommodation data was retrieved from the Romanian 
National Institute of Statistics. The data regarding the accommodation capacity of the area was overlapped with the map showing the presence of two types of gates: sculpted wooden gates and painted wooden ones.

The research was limited by the fact that the study of Szekely gates and their ethnocultural heritage value is insufficient, as their importance was only included in the specialized literature in the last decade. Mapping traditional gates is a recent endeavour for the local authorities from the study area, and as such, their study was challenging as there is no database available in terms of their distribution, their number, or their type. This meant that most of the study was done by field observation and field mapping, and building a database for the symbolistic and characterisation of Szekely gates from observation charts and interview guides that were later transformed into metadata and analyses.

The study has both local and international importance because it represents an endeavour to emphasise the heritage value of Szekely gates in a time when until recently their preservation and promotion has not constituted a priority. The results of this research could be emulated by other poorly explored tourism resources both in Romania but in other countries as well. This study aims to emphasise the real potential of Szekely gates for the preservation, promotion, and integration of this specific ethno-cultural symbol in the overall tourism image of the study area.

\section{Identifying the main areas of distribution for Szekely gates in Romania}

Szekely gates represent an ethno-cultural tourism resource located within areas inhabited by the Szekely population who are documented historically as living in Romanian territories since the 11th and 12th centuries (Popa-Lisseanu, 2003). Szekely gates are a tangible heritage element, which reflects the strong interaction between spatial structure and ethnicity (Madut, 2017). Their spreading, as proved by the results of the observations charts the authors realized is more concentrated in localities from the Covasna and Harghita Counties and only partially in Mureş County. Out of the total localities analysed the predominant form of gates is sculpted wooden gates $83.3 \%$ with the rest of $16.7 \%$ being painted wooden gates. The latter category of gates was found in 10 localities from Mureş County (the villages Corund, Dealu, Şimoneşti, Cehețel, Sâncrai, Făncel, Feliceni, Brădeşti, Delniţa, Sândominic, Bârzava, Satu Mare and the town of Odorheiul Secuiesc) and in Vârghiş, from Covasna County.

The poor representation of painted wooden gates is justified by the lack of artisans that still know this technique and the symbolism of the paintings and as such, the gates that still survived today have an added importance because of their historical value and their dwindling number.

Sculpted wooden gates are found in most of the rural areas where the Szekely population are the majority and sometimes even in towns as entrances to different official institutions. They function as a mark for the contemporary affirmation of an ethnic identity whose safekeeping represents an important task (Silva and Leal, 2015) and they can simultaneously operate as a tourism resource (Figure 1). 


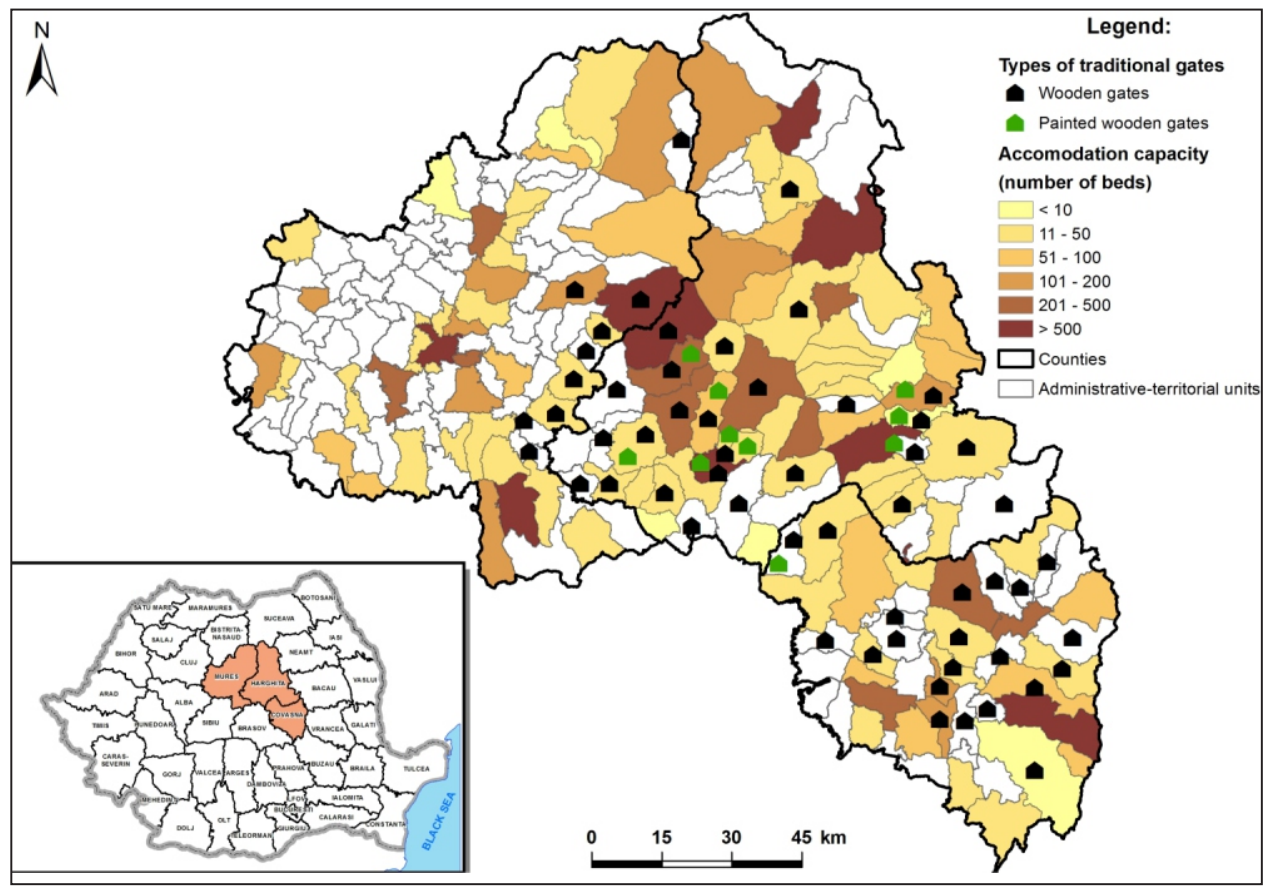

Figure 1. Szekely gates distribution area (resulted from field investigations)

\section{The significance of the main traditional symbols (motifs, colours, sculptures, paintings)}

For the Romanian population, the gate itself is a symbol because of its role of marking the border of the household, a personal space that is meant to protect the family, and which in turns needs to be protected. The traditional gate even more than an ordinary one, keeps its worldly function of keeping the animals from leaving the perimeter and protects them from potential negative exogenous factors, but it is also constructed as a metaphorical guardian with its sculpted or painted symbols meant to dispel evil or bring prosperity to the household and its inhabitants.

The decorative elements found on Szekely gates are varied and incredibly complex and have a high aesthetic value that further increase their value as a cultural tourism heritage resource. The data gathered from the interview guides shows that the most common symbols used for sculpted wooden gates are the sun, the tulip and flowers in general, with each of these being mentioned by $8.6 \%$ of the respondents, followed by the moon (4.8\%), and the rooster and the stag (3.9\%). Geometrical shapes and Szekely specific symbols like specific coats of arms $(1.9 \%)$ or the Szekely moustache $(2.8 \%)$, the tree of life $(2.9 \%)$, the rope (1\%), and other zoomorphic or floral motifs were mentioned as dominating the traditional local cultural both in the past but also nowadays by the artisans. For the painted wooden gates the same symbols are being used, and in addition, two colours were designated as being traditional: red and green (1.9\%) (Figure 2).

All these symbols can be found on both sculpted wooden gates and wooden painted gates (Photo 1). The painted gates are less represented because they are 


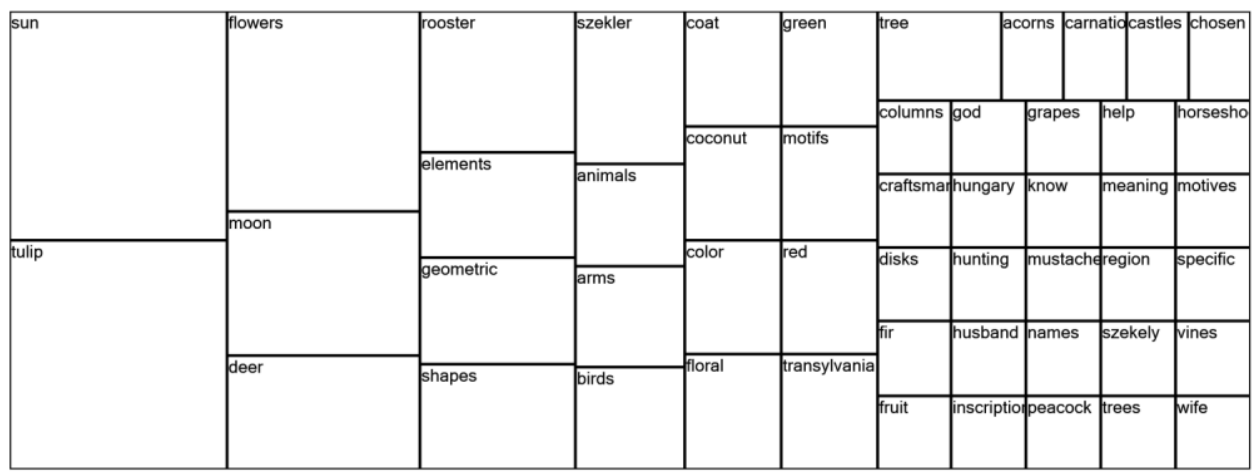

Figure 2. Symbols frequency on Szekely gates. Extras with Nvivo 11.

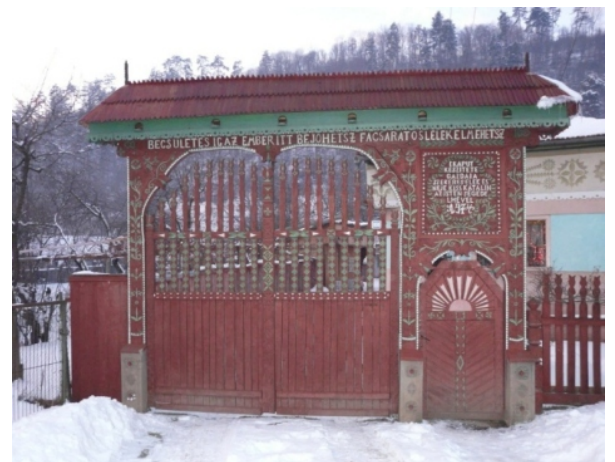

Photo 1a. Painted Szekely gate Source: Mihaela Preda, 2017

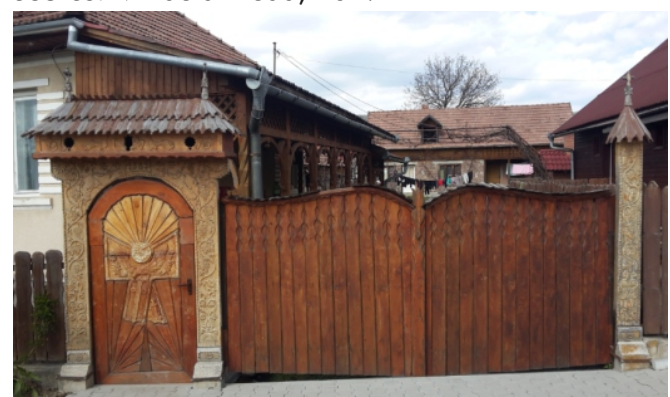

Photo 2a. Sculpted Szekely gate

Source: Iuliana Vijulie, 2017

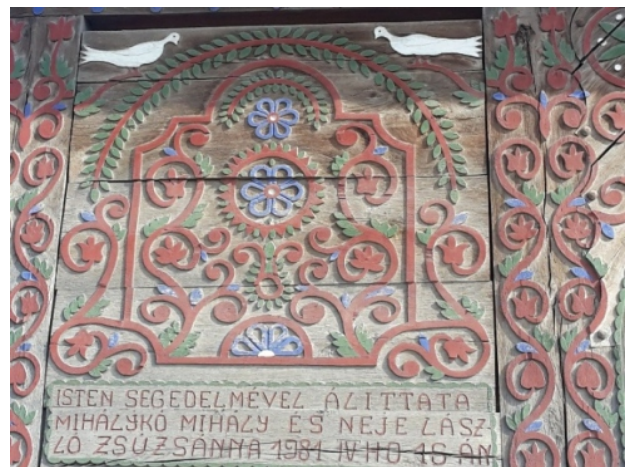

Photo 1b. Details of a oaninted Szekely gate

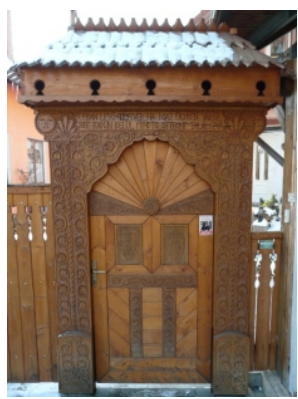

Photo 2b. Details of a sculpted gate

more laborious and time-consuming to make and infer higher costs. After the wood is prepared and sculpted the artisan paints the different elements on the gate, in order to further emphasise them and to better and more efficiently transmit their meaning to the viewers. Green is a specific Szekely colour that is seldom used on painted gates, it can be found on their flag and their coats of arms, but one can also see red on these gates, a colour deeply rooted in the traditional Romanian culture, which symbolises fertility and prosperity.

Wooden sculpted gates are more common. The observation charts showed that there are differences in terms of size, but regardless of that, they are always made out of the little gate, frequently used by the family and visitors and the larger gate used by animals or carts. Depending on its size the gate can be simple (Photo 2a) or covered (Photo 1a). 
$78 \%$ of the respondents declared that there is direct correlation between the dimension of the gate and the social status of the owner as the larger more heavily ornamented gates usually reflect a more important and wealthy family. According to $88 \%$ of the responses, for the gates that are being build today the size is directly proportional with the financial status of the owner which is partially explained by its costs as an imposing wooden gate can cost up to 2,500 euros.

The traditional Szekely gates need to be analysed from the perspective of their symbolistic charge, as sculpted wooden gates are not unique to this area. In Romania, sculpted wooden gates are part of the national cultural heritage and can be found in other ethnic regions of the country such as Maramuress, Bucovina or sub-Carpathian Oltenia. This is why the in-depth analysis of the dimension, architectural style, and especially the symbols is important; these specific features differentiate Szekely gates from those located in other Romanian regions.

Our research shows that the symbols seen of Szekely gates fall into two categories: universal symbols, based mostly on Romanian tradition, that appear on gates in other areas as well and Szekely specific symbols that can only be seen on gates from areas inhabited exclusively by this ethnic population. The first category includes cosmic symbols, such as the sun and the moon; zoomorphic symbols like the rooster, the stag; floral symbols like the tree for example and the symbol of the rope. These symbols are equally used on other Romanian wooden gates as they have deep ancestral meanings (Ilieş et al., 2011).

The second category of symbols has specific ethnic value and range from the Szekely moustache, several coats of arms, as well as Hungarian texts that offer information about the name of the owners, year of construction, messages for the visitors or religious fragments. Another specificity of gates from this area is the dovecote, which can contain multiple pigeon nests. They can symbolise either the months of the year (if the gate is large enough) or the souls of the deceased (Ştefan, 2014). In the same category, we can include certain floral symbol such as the tulip, which can be found exclusively on these gates, but its significance is not always known even by the local population. $96 \%$ of the interviewed population that have traditional wooden gates declared that they do not know the meaning of the tulip and that its presence on the gate is explained by the fact that it is an inherited symbol or because the artisan chose to put it there. The rest of $4 \%$ identified the tulip as an ethnic-cultural symbol pertaining exclusively to the Szekely population; they said they inherited it from the Ottomans who used beforehand (Overholser, 2010).

Historically, wood was the main construction material for all households, especially in the Carpathian and sub-Carpathian areas where it represented the most available resource. The areas with a high representation of Szekely gates are included in such forested areas, with both hardwood and coniferous forests dominating here. If today wood has limited construction purposes, in the past it was use for the building of the house itself, animal shelters, fences and gates and other household items. According to our interview guide, the current gates are mostly made out of oak, followed by beech and fir (Table 1).

It is very important to establish the year the gates were constructed, as it is a proof of the local population' willingness to keep their traditional culture and 
Table 1. Type of wood used for Szekely gates. Extras with Nvivo 11.

\begin{tabular}{ccccc}
\hline Word & Length & Count & Weighted Percentage (\%) & Similar Words \\
\hline oak & 3 & 12 & 60.00 & oak \\
beech & 5 & 4 & 20.00 & beech \\
fir & 3 & 4 & 20.00 & fir \\
\hline
\end{tabular}

Source: Semi-structured interviews

Table 2. Szekely gates by construction year. Extras from Nvivo 11.

\begin{tabular}{ccccc}
\hline Word & Length & Count & Weighted Percentage (\%) & Similar Words \\
\hline 2007 & 4 & 5 & 25.00 & 2007 \\
1978 & 4 & 2 & 10.00 & 1978 \\
1991 & 4 & 2 & 10.00 & 1991 \\
2013 & 4 & 2 & 10.00 & 2013 \\
1958 & 4 & 1 & 5.00 & 1958 \\
1975 & 4 & 1 & 5.00 & 1975 \\
1980 & 4 & 1 & 5.00 & 1980 \\
1985 & 4 & 1 & 5.00 & 1985 \\
1989 & 4 & 1 & 5.00 & 1989 \\
1995 & 4 & 1 & 5.00 & 1995 \\
1996 & 4 & 1 & 5.00 & 1996 \\
2002 & 4 & 1 & 5.00 & 2002 \\
2008 & 4 & 1 & 5.00 & 2008 \\
\hline
\end{tabular}

Source: Semi-structured interviews

transmit it to future generations. Surprisingly, according to the data generated by the interview guides, most pf the gates were built in 2007. This means the local population intends to revive the Szekely tradition (Table 2) and generally corresponds to their efforts as well as the efforts of authorities from other areas to affirm and reinforce their ethnic identity in a contemporary global world through tourism, and specifically through tourism in the countryside (Silva and Leal, 2015) which holds a powerful ethnographic component.

Other gates date from the 90s and even more recently from 2002, 2008 and 2013. The age of the rest of the gates identified differs with some of them being more than 30 years old. The authors concluded that there is a real interest from the local population to preserve the cultural heritage that they have received from their predecessors and as such to define a real ethnographic area with genuine potential for future tourism capitalisation.

\section{The level of current national and international tourism promotion}

The success of the tourism promotion of cultural heritage, namely the traditional gates, depends on their degree of representation and preservation.

The interview guides showed that the territorial representation of the Szekely traditional gates is borne from an affective-emotional range of reasoning rather than an economic-financial one, as most of the interviewed population was not aware of the possibility of using these fates as tourism resources. They key words used by the owners of such gates when talking about their motivation for keeping them are represented in Figure 3. Most of discussions (97\%) centred on the importance of keeping tradition alive which in this case translated in keeping the traditional wooden gates (Figure 3). 


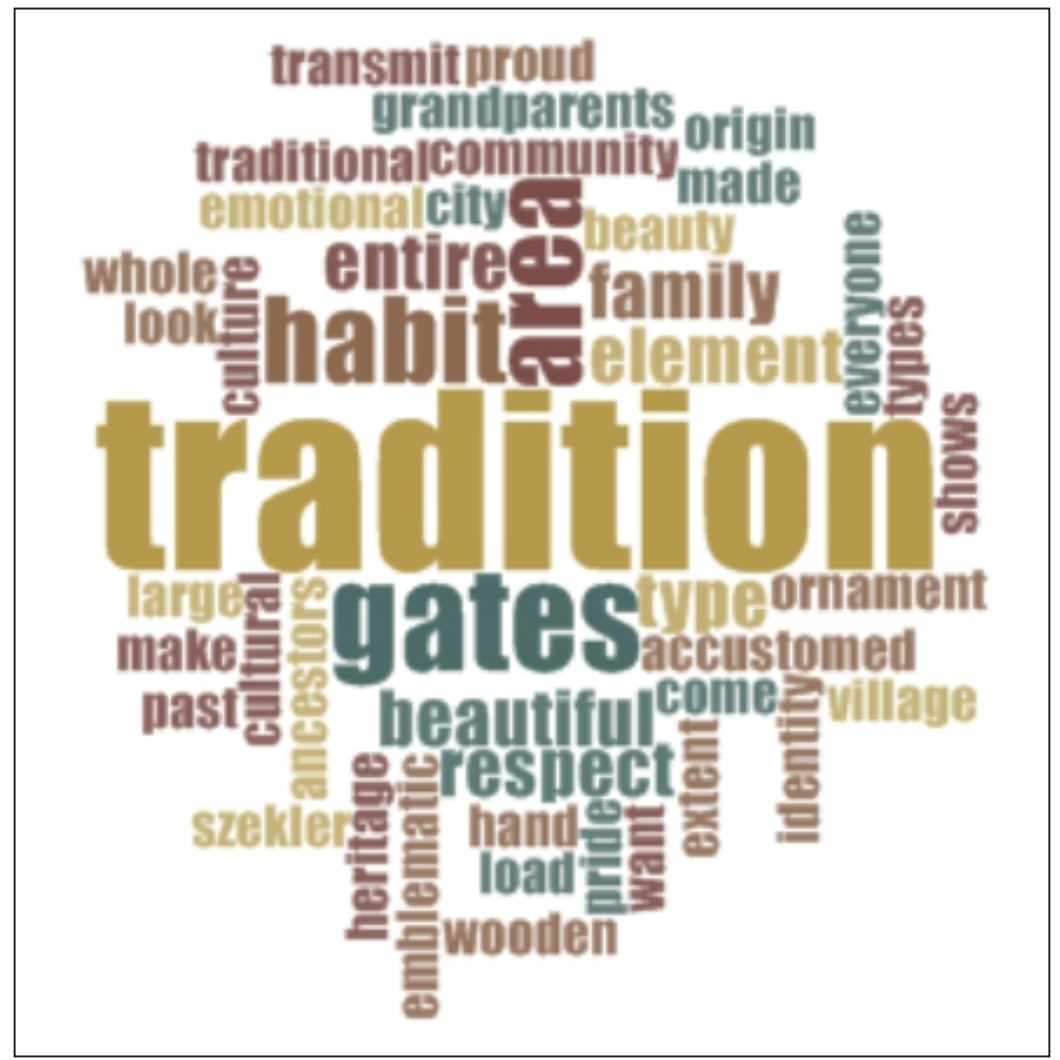

Figure 3. Motivation for keeping the Szekely gates. Extras from Nvivo 11.

The second most frequently used words are habit and area, proving that the wooden gates are seen as a custom kept by the population leaving in the region, and respected by the entire community, who out of solidarity with their peers choose to maintain the existing ones or build new ones.

The third most used group of words are beautiful, respect, and family element, showing that apart from keeping a tradition that respects their elders many of the gate owners see it as beautification of their household, a mere element of aesthetic value.

Other reasons for still keeping the traditional wooden gates as part of their household were related to ethnic identity (identity, cultural, ancestors, proud, grandparents, origin). These answers also include references to the gates' unique cultural value; the local population acknowledged that the specificities and individual elements of the Szekely gates play an essential role in conserving their ethnic tradition. None of the respondents, however, saw the presence of traditional wooden gates as a potential financial resource. In fact, the reasons for the preservation of the traditional Szekely gates do not have an economic basis, as they are not perceived as resources that could help develop cultural tourism in the area. For the local population, the traditional gates are a sign of their culture, a sign of pride or aesthetic or practical representation, passed on from one generation to another. 


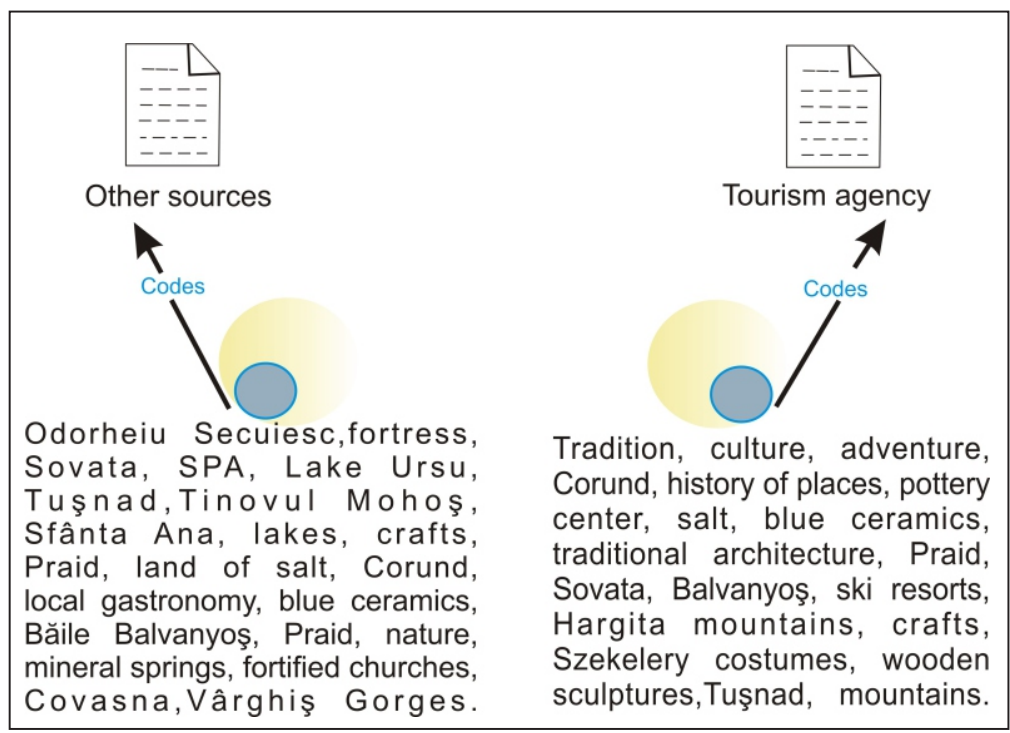

Figure 4. Promoting the tourism potential of areas with Szekely. Extras from Nvivo 11.

The authors analysed the level of national or international promotion by scanning the online media for mentions of Szekely gates. Two different types of online actors were analysed in order two measure their perspective: the more marketing specialised tourism promotional sites and the more casual or accidental tourism-related sites: local authorities' websites (local councils, city halls) or travel blogs. The keywords of this analysis appear in Figure 4, which proves that specialised tourism agencies do not include in their offers any reference to Szekely gates. They promote in some degree the traditional architecture but do not explicitly mention wooden Szekely gates.

Tourism agencies construct their holiday packages on the already existing tourism potential and usually promote the Praid saltworks or salt lakes, the Sovata SPA, Balvanyos, Tusnad, skiing opportunities in the area. They mention Szekely culture in reference to Corund pottery, national costumes, and woodworking, but none of the analysed agencies mentions specifically and explicitly the traditional Szekely gates as tourism attractions that hold unique characteristics from an ethnocultural heritage point of view.

The second category of online actors promotes the same tourism attractions namely the towns of Odorheiul Secuiesc and Covasna, the Balvanyos and Sovata SPAs, the salt attractions around Praid as well as Sf. Ana Lake and fortified churches. They also mention the cultural heritage of the area but again reference Corund pottery, and, maybe more distinctively Szekely specific gastronomy.

Another drawback is the fact that the majority of the online sources are in Romanian with some of them having a Hungarian translation option, which sets the access to this information to internal tourists and limits the spectrum of international tourists. The Hungarian option for most of the web pages is determined by the fact that the area promoted has a large Szekely population and in the same time addresses the Hungarian speaking population that usually frequents the local SPAs (Balvanyos and Sovata). The traditional Szekely gates, unlike other wooden gates found in Romania for example in Maramureş, are 
scarcely mentioned or not promoted at all, because the local population, local decision-making actors, and economic agents are not aware of their tourism importance.

\section{The integration of ethno-cultural heritage in tourism itineraries}

Traditional Szekely gates are a poorly capitalised resource located in a highly visible and viable tourism area. The marketing strategies of all main decision making actors have neglected until now the potential of these gates, which managed to survive only as a result of the conservation efforts of the local communities in their attempt to preserve their traditions. Until recently there were no concerns about preserving or maintaining this type of heritage. The first step in this direction was in 2009 when the local councils and NGO type private entrepreneurs initiated rehabilitation policies for 23 monuments (initiated for example by Satu Mare Local Council, Harghita County) or measures to inventory and rehabilitate traditional gates in their county (by Harghita County Council). The promotion of Szekely gates could lead to a proper tourism capitalisation of these resources regarding heritage tourism, considering their aesthetic value and the fact that this type of tourism already uses similar gates in other parts of the country (the Maramureş traditional gates).

The localities with the best accommodation capacity are Miercurea Ciuc, Gheorghieni, Băile Tuşnad, Odorheiul Secuiesc, Borsec (Harghita County), Târgu Mureş, Sighişoara, Sovata from Mureş County, and the town of Covasna from its namesake county. Their locations are mostly known for their SPA type tourism due to the presence here of important mineral springs but also cultural and business tourism. Localities that thrive regarding both accommodation capacity and proper representation of traditional gates are Corund, Praid, Zetea, Voşlabeni and Turia. Even here, the accommodation capacity is well developed due to the area's popular mountainous and SPA tourism. The accommodation capacity of other localities where traditional Szekely gates are located is insufficient or lacking (Figure 1).

Corund and Praid are obvious exceptions for the area, but they developed their tourism activity mainly based mostly on their natural potential, and namely saltworks (Praid Salina and Praid SPA complex) and their mountainous location through the Harghita Mountains winter sport facilities and not so much based on their cultural heritage. The promotion of the Corund pottery facilities and workshops with their specificity usually comes second to other activities and represent a transit objective to other points in the area.

The Szekely gates are not presently an important tourism objective, but they represent an important untapped source for increasing the tourism revenue of the local community and an instrument for helping preserve the ethnic identity of this population. The integration of ethno-cultural heritage in tourism itineraries is not a difficult endeavour considering the area is an already wellknown tourism destination, has a sufficient accommodation infrastructure and a good promotion platform. This objective can be achieved through the continuous endeavour of local and county authorities to rehabilitate the existing gates and encourage the community to build new ones. Other sets of activities that 
need to be undertaken are constructing marketing strategies that integrate Szekely gates in existing tourism itineraries and promoting them both nationally and internationally.

The accommodation capacity shown through the number of available beds for each locality proves that it is not always correlated with the distribution of this specific ethno-cultural heritage element.

\section{Conclusions}

The main objective of our study was to identity and map traditional Szekely gates. This area proved to be significant and overlapping with much of the area inhabited by the Szekely ethnic minority, covering the Harghita and Covasna counties and much of Mureş County. The field investigation found that $83.3 \%$ of the gates identified were sculpted wooden gates and a much smaller percentage of only $16.7 \%$ were wooden painted gates. An integration of ethno-cultural heritage in tourism itineraries was considered by using data of accommodation infrastructure; the authors found that the established tourism destinations of the study area are have a sufficient capacity, although sometimes these do not correspond with the areas where Szekely gates are represented the best.

Another objective was to identify the symbols found on traditional Szekely gates. This step of the research revealed that these gates contain many unique elements, not found in other ethnocultural regions of the country, symbols that have a direct connection with Szekely ethnic minority and their history (e.g. the tulip, the Szekely moustache, Szekely coats of arms, and Hungarian texts). Other specific aspects of these gates include the presence of a dovecote or specific colours used in painting the gates. The uniqueness of constructing the gates and symbols found on them increase their potential for tourism promotion.

The authors analysed online sources in order to assess the level of tourism promotion of Szekely gates. They concluded that Szekely gates are mostly unknown internationally, and they only have limited local importance nationally. The gates are not included in tourism circuits or itineraries. The authors consider that the correlation between the accommodation capacity and the gates distribution is strong enough to sustain creating tourism itineraries (both at a national and international level) that would incorporate the traditional Szekely gates as viable tourism resources.

The results of the study proved that traditional Szekely gates are presently an element of cultural heritage that only survives because of the local communities' desire of preserving their identity and tradition but without acknowledging their tourism value. They are an untapped tourism resource that if capitalised at their true potential can become a genuine heritage tourism element; they could also emphasises the region's unique ethnic identity.

\section{Acknowledgements}

All co-authors had equal contributions in this paper. 


\section{References}

André, M. (2011), Tourism and identity, Brussels: Centre Maurits Coppieters, 15 December 2017, (https://goo.gl/oTm1Rf).

Azmi, E. and Ismail, M.Z. (2016), "Cultural Heritage Tourism: Kapitan Keling mosque as a focal point \& symbolic identity for Indian muslim in Penang", Procedia - Social and Behavioral Sciences, Jakarta: Annual Serial Landmark International Conferences on Quality of Life ASEAN-Turkey.

Ballesteros, E.R. and Ramírez, M.H. (2006), "Identity and community-Reflections on the development of mining heritage tourism in Southern Spain", Tourism Management, vol. 28, no. 3, p. 677-687.

Blismas, N.G. and Dainty, A.R.J. (2003), "Computer-aided qualitative data analysis: Panacea or paradox?", Building research छ information, vol. 31, no. 6, p. 455-463.

Bucata, R. (2017), "Porțile secuiești și meșterul care le știe secretele", Think outside the box - jurnalism independent, 1 February 2018, (https://goo.gl/2X2DXS).

Cohen, A.P (1975), The management of myths: the politics of legitimation in a Newfoundland community, Manchester: Manchester University Press.

Cohen, A.P (1993), "Culture as identity: an anthropologist's view, New Literary History", Culture and Everyday Life, vol. 24, no. 1, pp.195-209.

Comşa, N. (2013), "Traditional wooden gates in the Szekler land", ProLigno, vol. 9, no. 3, p. 42-50.

Dessein, J., Soini, K., Fairclough, G. and Horlings, L. (eds) (2015), "Culture in, for and as Sustainable Development", Conclusions from the COST Action IS1007 Investigating Cultural Sustainability, Finland: University of Jyväskylä.

Dumbrăveanu, D., Crăciun, A. and Tudoricu, A. (2016), "Principles of interpretation, tourism and heritage interpretation - the experience of Romanian museums", Human Geographies - Journal of Studies and Research in Human Geography, vol. 10, no. 1, p. 59-75.

Ilieş, A., Ilieş, D.C., Wendt, J.A. and Herman, V.A. (2011), "The Romanian rural architectural heritage from Maramureş Land-Personality, distinctiveness and protection", Studia Universitatis Babes-Bolyai - Geographia, no. 2, p. 187-196.

Jones, M.L. (2007), "Using software to analyse qualitative data", Malaysian Journal of Qualitative Research, vol. 1, no. 1, p. 64-76.

Lica, D. and Coşereanu, C. (2010), Civilizaţia lemnului la Români, Braşov: Editura Universităţii 'Transilvania'.

Lungu, S. (2015), "Cele mai frumoase obiective turistice din Ţinutul Secuiesc. Lacul Sfânta Ana şi Poiana Zânelor, adevărate minuni ale naturii", Adevărul, 15 December 2017, (https://goo.gl/ZqKeUv).

Lussetyowati, T. (2015), "Preservation and Conservation through Cultural Heritage Tourism. Case Study: Musi Riverside Palembang", Procedia - Social and Behavioral Sciences, Bandung, Indonesia: 5th Arte Polis International Conference and Workshop - Reflections on Creativity: Public Engagement and The Making of Place, p. $401-406$.

Madut, K.K. (2017), "Spatiality of ethnic identity and construction of sociopolitical interaction in South Sudan", Human Geographies - Journal of Studies and Research in Human Geography, vol. 11, no. 2, p. 181-195.

Markus, H. And Kunda, Z. (1986), "Stability and malleability of the self concept", 
Journal of Personality and Social Psychology, vol. 51, no. 4, p. 858-866.

Matei, E. (2011), "The ecotourism's development in the Romanian Carpathians' protected areas: facts, figures and needs", Human Geographies - Journal of Studies and Research in Human Geography, vol. 5, no. 2, p. 31-39.

NA (2007), "Covasna - staţiune balneoclimaterică de interes naţional - Atracţiile turistice în zona Covasnei, Clermonthotel, 11 January 2018, (https://goo.gl/3dy9f8).

NA (2013), "Obiective turistice în Covasna şi împrejurimi", Itour.ro, 11 January 2018, (https://goo.gl/pwCQei).

NA (2015), "10 cele mai frumoase locuri din judeţul Covasna", BunaDimineata.ro, 11 January 2018, (https://goo.gl/ubEhkg).

NA (2015), "10 cele mai frumoase locuri din județul Mureş", BunaDimineata.ro, 11 January 2018, (https://goo.gl/Usvo3E).

NA (2015), "Ce să vizităm în Covasna într-un weekend?", HotelGuru.ro, 11 January 2018, (https://goo.gl/6znYHm).

NA (2016), "10 cele mai frumoase locuri din judeţul Harghita", BunaDimineata.ro, 11 January 2018, (https://goo.gl/RT6of6).

NA (2016), "12 lucruri de făcut şi văzut în judeţul Covasna", tuktuk.ro, 11 January 2018, (https://goo.gl/GShlex).

NA (2017), "10 motive pentru a vizita Ţinutul Secuiesc", infoturism.ro, 15 December 2017, (https://goo.gl/gQoQYb).

NA (2017), "Atracții şi obiective turistice din judeţul Covasna - Descoperă România și vezi aici lista cu locuri, atracții și obiective turistice din județul Covasna", EuRomânia, 11 January 2018, (https://goo.gl/H7vY5b).

NA (2017), "Atracții și obiective turistice din judeţul Harghita - Descoperă România și vezi aici lista cu locuri, atracții și obiective turistice din judeţul Harghita", EuRomânia, 11 January 2018, (https://goo.gl/pDSEiV).

NA (2017), "Ghid turistic Ţinutul Secuiesc", Infotour, 15 December 2017, (https://goo.gl/D9W1fZ).

NA (2017), Grupuri de lucru, Consiliul Judetean Harghita, 11 January 2018, (https://goo.gl/voVZxP).

NA (2017), "Harghita - ce putem vizita într-un weekend?", HotelGuru.ro, 11 January 2018, (https://goo.gl/hnwys3).

NA (2017), "Mureş - Transilvania e timpul să veniţi", Asociaţia Judeţeană de turism Mureş, 11 January 2018, (https://goo.gl/zFiALJ).

NA (2017), "Obiective turistice în Covasna", DirectBooking, 11 January 2018, (https://goo.gl/62m3Wo).

NA (2017), "Vacanţe în Covasna: simple, autentice, relaxante, tradiţionale!", AmosNews, 15 december 2017, (https://goo.gl/Xe4UQu).

NA (2017), "Valorile tradiţionale ale Ţinutului Secuiesc promovate la Romexpo", AmosNews, 15 december 2017, (https://goo.gl/YaFMTG).

NA (2018), "Destinaţii turistice care merit vizitate pe parcursul unui drum prin Ardeal şi Secuime", ozonturist.ro, 1 February 2018, (https://goo.gl/z8Qcb6).

NA (2018), "Obiective turistice din judeţul Mureş", Darina - hotels E stores, 1 February 2018, (https://goo.gl/mhBSSE).

NA (2018), "Oportunităţile turistice din județul Harghita", harghita.ro, 1 February 2018, (https://goo.gl/Pe7NHL).

NA (2018), "Turism", JudeţulHarghita.ro, 1 February 2018, 
(https://goo.gl/ZeQNUF).

NA (2018), "Vizitează", visitharghita.ro, 11 January 2018, (https://goo.gl/uVXdgj).

NA (2018), "Cazare în Transilvania, Ţinutul Secuiesc, Secuime: Harghita, Covasna, Mureş", Cazare în Secuime - Transilvania, 11 January 2018, (https://goo.gl/udFv14).

OECD (2009), The impact of Culture on Tourism, Paris: OECD Publishing.

Overholser, L. (2010), "Ferenc Keresztesi: Traditional Hungarian WoodCarving, Voices", The Journal of New York Folklore, vol. 36, no. 3/4, p. 26-29.

Pop, V., Pop, C. and Pop, M. (2013), "Features of sustainable rural development in Maramureş", Lucrări ştiințifice, series I, vol. 15, no. 1, p. 266-273.

Popa-Lisseanu, G. (2003), Originea secuilor şi secuizarea românilor, Bucureşti: România Pur şi Simplu.

Poria, Y. and Ashworth, G. (2009), "Heritage Tourism - Current Resource for Conflict", Annals of Tourism Research, vol. 36, no. 3, p. 522-525.

Poria, Y., Butler, R. and Airey, D. (2003), "The core of heritage tourism", Annals of Tourism Research, vol. 30, no. 1, p. 238-254.

Portase, O. (2016), "Ținutul Secuiesc, locul de care te indrăgosteşti iremediabil", jurnalul.ro, 11 January 2018, (https://goo.gl/wnkpSH).

Silva, L. and Leal, J. (2015), "Rural tourism and national identity building in contemporary Europe: Evidence from Portugal", Journal of Rural Studies, no. 38, p. 109-119.

Ştefan, G. (2014), "DESTINAŢIE: ROMÂNIA/Satu Mare (Harghita), localitatea porţilor secuieşti cunoscute în întreaga Europă, AGERPRES, 1 February 2018, (https://goo.gl/FYN6Cu).

Suciu, S. (2017), "Top cinci obiective turistice în Harghita. De la singurul lac vulcanic din România la peştera din care picură aur", Adevărul, 1 February 2018, (https://goo.gl/i3geui).

Tajfel, H. (1981), Human Groups and Social Categories: Studies in Social Psychology, Cambridge: Cambridge University Press.

Traveler, A. (2015), "50 de obiective de văzut în Ţinutul Secuiesc", Enciclopedia călătorului independent, 1 February 2018, (https://goo.gl/892em4).

Webster, C. (1994), "Effects of ethnic identification on marital roles in the purchase decision process", Journal of Consumer Research, vol. 21, p. 319-331.

Yang, J., Ryan, C. and Zhang, L. (2013), "Ethnic minority tourism in China e Han perspectives of Tuva figures in a landscape", Tourism Management, vol. 36, p. 45-56.

Yang, L. (2011), "Ethnic tourism and cultural representation", Annals of Tourism Research, vol. 38, no. 2, p. 561-585. 